\title{
Is Divorce Predictable among Iranian Couples?
}

Gholamhosein Shahraki, Zahra Sedaghat, Mohammad Fararouei, and Zibaneh Tabeshfar

\begin{abstract}
Divorce is considered as an important social and public health concern worldwide. The aim of this study was to identify divorce's social and economic contributors among Iranian couples. This case-control study was conducted on 60 divorced and their neighboring 64 still-married couples with approximately the same date of marriage. The required information was obtained from consultant administrated forms which are used routinely by Iranian family consulting centers. An interview-administered questionnaire with almost the same structure and questions was used to obtain information from still-married couples. Based on the results of multivariable analysis and (stepwise) selection of the study variables, significant associations between divorce and employment of both husbands and wives, education of husband, and the couple's accommodation statuses were found. Accordingly, wife's (OR unemployed/self-employed=4.97, 95\%CI: 1.38-21.61, $\mathrm{P}=0.001)$ and husband's (OR unemployed/self-employed $=17.45$, 95\%CI: 3.56-123.98, $\mathrm{P}=0.001)$ unemployment, less educated husband's ( $\mathrm{OR}$ primary or secondary/higher education $=23.98,95 \% \mathrm{CI}=4.04-237.05, \mathrm{p}=0.001)$ and couples with shared accommodation $(\mathrm{OR}$ dependent/independent $=5.99,95 \% \mathrm{CI}=2.54-17.72, \mathrm{P}<0.001)$ were at higher risk of divorce. ROC analysis suggested that divorce can be confidently predicted by the above factors (AUC $=0.882$ 95\%CI: 0.816-0.948) with $66.7 \%$ sensitivity and $92.6 \%$ specificity. This study introduced several predictors, which can be used by family consultants and psychologists to recognize high risk marrying or married couples to prevent divorce and to help couples to obtain and sustain healthier marriages and stronger family relationships.
\end{abstract}

Keywords: couple, divorce, family, prediction, risk factors, social concern

Gholamhosein Shahraki, Social Determinants of Health Research Center, Yasuj University of Medical Sciences, Yasuj, Iran.

Zahra Sedaghat, Research Center for Health Sciences, Department Epidemiology, Shiraz University of Medical Sciences, Shiraz, Iran.

Mohammad Fararouei, HIV/AIDs Research Center, Shiraz University of Medical Sciences, Iran.

Zibaneh Tabeshfar. ${ }^{4}$ Social Determinants of Health Research Center, Yasuj University of Medical Sciences, Yasuj, Iran. 


\section{Introduction}

Divorce is a significant concern to the public. It affects the social, physical and mental statuses of all family members and in that respect, the community's health (Adults, Brown, \& Lin, 2018). It is suggested that divorce deteriorates an individual's quality of life, worsens the prognosis of diseases, and even hastens death (Sbarra, Hasselmo, \& Bourassa, 2015). However, recent statistics suggest that having a successful marriage is not easily achievable.

In Spain, the rate of divorce is rising so sharply that it is considered as a social concern (Bernardi \& Martínez-Pastor, 2011). In the United States, each year more than one million marriages end up in divorce (nearly 45\% of annual marriages)(Brown \& Lin, 2012; Greenwood, Guner, Santos, \& Kocharkov, 2016). It is also suggested that among Iranian couples, possibly due to the recent social and demographic changes including urbanization and women's financial independency, the rate of divorce is rising constantly (Farzanegan \& Gholipour, 2016). In fact, the divorce to marriage ratio in 1980, 2000 and 2012 raised from $6.9 \%$ to $8.24 \%$ and $12.29 \%$ respectively (Farzanegan \& Gholipour, 2016). The divorced couples were predominantly newly married (for less than 3 years) and were predominantly under 30 years of age (Farzanegan \& Gholipour, 2016). The upward change of divorce among Iranian young couples has raised the government's concern. This is because, in addition to family and social harms, high divorce rates of such an extent are negatively affecting population growth in Iran (Farzanegan \& Gholipour, 2016).

Marriage, one of the most significant social events in any person's life, seems to be affected by numerous socio-demographic and economic factors (Janmardy, 2011). However, due to both complexity of marriage and differences between communities in cultural, religious and socio-economic aspects, the main contributors to divorce seem to be different in different countries, cities and even ethnic groups. With regard to these differences, numerous studies have been conducted to identify important contributors of divorce. The results of these studies introduced several personal and social factors (Fu, 2006; González-Val \& Marcén, 2012; Janmardy, 2011). For example, social disputes, economic recessions, and wars are suggested as playing important roles in couples getting divorce (Greenwood et al., 2016; Janmardy, 2011).

Among different socio-economic factors, migration, either inter or intra-nation, (Furtado, Marcén, \& Sevilla, 2013) and unemployment are identified as significant contributors to divorce (Amato \& Beattie, 2011). It is shown that social and financial difficulties due to unemployment and poverty lead to hostility among spouses. This, in turn, causes a significant reduction in a couple's satisfaction and happiness (Amato \& Beattie, 2011; Jensen \& Smith, 1990). For example, according to Henson (2005) and Jalovaara (2003), unemployment is an important contributor to couples' disputes (Hansen, 2005; Jalovaara, 2003) and pushes both husband and wife towards a more hostile family environment (Wolfinger, 2011).

Numerous studies have also been conducted that identifies the association between ethnicity and divorce (Hohmann-marriott \& Amato, 2008; Song, 2010). According to the results, partners from different ethnic (or cultural backgrounds) had a weaker relationship as compared to those from the same cultural and ethnic background. This, as the authors believe, is mainly due to less parental support and fewer shared values among couples from 
different cultures. Results of another study introduced age discrepancy between couples as an effective factor in divorce as this issue is associated with more marital dissolutions (Choi \& Cheung, 2017).

However, not all study results are universally consistent. In fact, different studies with different study populations provided results with different conclusions. For example, although several studies suggested a negative association between divorce and the age of couples (Amato \& Beattie, 2011; Cooney \& Dunne, 2001; Sweeney, 2010) Krinder (Kreider $\&$ Ellis, 2011) and Brown (Adults et al., 2018) achieved opposite results, that is, a direct association between the age of couples and divorce.

Although numerous studies on divorce associates have been carried out so far, the determinants of an unsuccessful marriage are not yet fully defined and we do not know why the rates of divorce are still increasing sharply (Gottman, 1994; Hochberg \& Kressel, 1996; Karabchuk, 2017). It seems that the determinants of divorce are highly associated with ethnic and cultural backgrounds and the economic status of a community (Song, 2010; Walker, 1992). The aim of this study was to identify socio-demographic or economic factors which are important in divorce, and whether these factors can be used to predict divorce. Like many other parts of the world, the sharp rise of divorce among Iranian couples requires an introduction of efficient preventive measures via better understanding of its determinants.

\section{Methods}

\section{Subjects and Methods}

This is a case-control study conducted on 60 divorced and 64 still-married couples. Divorced couples were selected among those who took the final legal step to divorce at family courts in Yasuj city, Iran. Divorce in Iran is deliberately set to be a complicated and lengthy process in order to make family judges sure that divorce is inevitable. Routinely, the divorcing couples are introduced to a specially trained psychologist who, along with consultation services, completes an interview-administered questionnaire. The interviewer collects a wide range of information regarding different aspects of the couple's life including their social and financial status and their family background. The consultation would go on for several sessions in order to change the couple's decision to divorce. Based on the results of the interview, detailed and reliable data is collected by the consultants.

\section{Selection of Case Group}

The wives of those couples who were about to receive the final report suggesting divorce (the case group) were asked to read and sign an informed consent form allowing the research team to have limited access to the information obtained during their interviews at the family consultant center. The family court granted the research team to have access to the files of 60 couples only. 


\section{Selection of the Control Group}

The control participating couples $(n=64)$ were selected among the neighbors of the divorcing couples. This was done to make the case and control groups socio-economically more comparable. A door-to-door sampling approach was applied to find out married couples with almost the same date of marriage (with \pm 1.5 years). After informed consent was obtained, the wife was interviewed by a female interviewer and an interview-administered questionnaire was completed. The selection of wives for the interview were based on the fact that due to cultural issues, Iranian men prefer to not talk about their private life especially their wives. No such restriction exists the other way around.

\section{Sample Size and Power Analysis}

The study population consisted of divorcing couples who were referred to a family consultant center during 2014 and obtained the final report from the family consultant to the court till the end of 2015. Posterior power calculation suggested $80 \%$ power and $5 \%$ type I error for the statistical tests to find a significant association between husband's job and risk of divorce.

\section{Patient and Public Involvement}

In open interviews with several divorcing couples, the couples provided the research team with useful ideas about the possible contributing factors of divorce, which helped in building the study questionnaire.

\section{Data Collection}

The required information was obtained from consultant-administrated forms, which are used routinely by the Iranian family consulting centers. An interview-administered questionnaire with almost the same structure and questions was used to obtain the required information from the wives of the control couples. The questionnaire was evaluated in a pilot study on 15 couples and a couple of questions regarding income and sexual behavior were excluded due to the unwillingness of the participants to answer the questions. The final questionnaire was completed during a door-to-door interview by a female health nurse to obtain required information from the control couples. The variables under study included, wife's age at marriage, type of wife's marriage (i.e. forced, in which the spouse was forced to marry and consent to marriage, in which the spouse willingly married her husband), agreement of wife's parents to their daughter's marriage, wife's employment status (unemployed, employed) wife's history of divorce, smoking, addiction and size of families in 
which the wives were raised. Also, the husband's age at marriage, type of husband's marriage (forced, consent to marriage), agreement of husband's parents to their son's marriage, husband's employment (unemployed, employed), husband's history of divorce, smoking, addiction, and size of families that the husbands were raised in. In addition, consanguinity of the couples, how the spouses were introduced to each other, and types of accommodation (landlord, tenant, living with family) were among the study variables.

\section{Statistical Analysis}

The data was analyzed using Stata software (version 12). Univariate analysis was used as a primary analysis strategy to measure the unadjusted associations between the study variables and divorce. All study variables are included in the univariate analysis. Multivariate logistic regression with stepwise selection strategy was applied to measure the adjusted associations between the study variables and divorce. Collinearity between the independent variables was tested using variance inflation factor index (VIF) which was set at 10. Due to the small sample size of some categories, the following qualitative variables were not included in the multivariable analysis: wife's history of addiction (very few reported addiction in both case and controls), wife's history of smoking (very few wives reported smoking in both case and controls), husband's previous marriage (very few husbands reported previous marriages in both case and controls), type of husband's marriage, and divorce history in husband's family. Akaike information criterion (AIC) was used to compare fitness of models. The final logistic model was then used to measure the ability of the associated factors in predicting divorce among Iranian couples. R statistical Package (pROC) was used to measure sensitivity, specificity and AUC and to construct ROC curve analysis.

\section{Results}

The demographic and social characteristics of case and control groups are shown in Table 1. Compared to controls, the divorcing couples were predominantly tenant $(54.90 \%$ among cases compared to $23.64 \%$ among controls, $\mathrm{p}<0.001$ ), the husbands were predominately unemployed $(31.25 \%$ among cases compared to $9.38 \%$ among controls, $\mathrm{p}=0.003)$, were less educated $(74.58 \%$ were illiterate among cases compared to $46.88 \%$ among controls, $\mathrm{p}<0.001)$ and husbands were predominantly smoker $(51.02 \%$ among cases compared to $25.86 \%$ among controls, $\mathrm{p}=0.007$ ). Although the husbands in the divorcing couples were raised in bigger parental families $(87.50 \%$ had more than four family members compared to $77.05 \%$ among controls, $\mathrm{p}=0.16$ ) and were predominantly under pressure by their parents to marry (9.62 among cases compared to $3.39 \%$ among controls, $p=0.17$ ), the differences were not significant. Similarly, wives in the divorcing couples group were raised in bigger families $(89.80 \%$ had more than four family members compared to $76.67 \%$ among, 
control group, $\mathrm{p}=0.07)$, were forced to marry $(11.76 \%$ among cases compared to $10.00 \%$ among controls, $\mathrm{p}=0.76)$ and their family had more history of divorce $(14.00 \%$ among cases compared to $5.36 \%$ among controls, $\mathrm{p}=0.12$ ).

After the stepwise selection of the study variables, the results of multivariate logistic regression suggested that couple's age and educational status significantly improve the ability of the logistic model in predicting the couples' divorce. As a result, although the ORs for wives' education and age of spouses at marriage were not individually significant, these variables along with the others, which were significantly associated with the chance of divorce, were remained in the final multivariate model and are discussed here. Based on the results, which are presented in Table 2, significant contribution to the ability of model in predicting divorce were found for wife's employment $(\mathrm{OR}$ unemployed/self-employed $=4.67,95 \% \mathrm{CI}$ : 1.38-21.61, $\mathrm{P}=0.019)$, husband's employment ( $\mathrm{OR}$ unemployed/self-employed $=17.45$, 95\%CI: 3.56$123.98, \mathrm{P}<0.001)$, husband's education $(\mathrm{OR}$ primary or secondary/higher education $=23.98,95 \% \mathrm{CI}=4.04$ 237.05, $\mathrm{p}<0.001)$ and accommodation statuses of the couples ( $\mathrm{OR}$ dependent/independent $=5.99$, 95\% $\mathrm{CI}=2.54-17.72, \mathrm{P}<0.001)$.

The final logistic model (Model 1) was used to predict divorce and conduct sensitivity analysis. The results suggested that the final model with the above variables can predict divorce fairly well (AUC $=0.882$ 95\%CI: $0.816-0.948$ ) with $66.7 \%$ sensitivity and $92.6 \%$ specificity (Figure 1).

\section{Model 1: The Final Logistic Model to Predict Divorce}

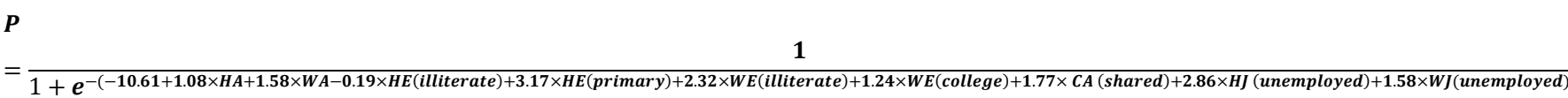

$\mathrm{HA}=\mathrm{HA}=$ Husband's age, $\mathrm{HE}=$ Husbands education, WA= Wife's age, $\mathrm{CA}=$ Couple's accommodation, $\mathrm{HJ}=$ Husbands job, WJ= Wife's job

\section{Discussion}

The present study examined the relationship between a wide range of sociodemographic and marital characteristics of participating couples and the risk of divorce. The results suggested that significant (unadjusted) associations exists between divorce and couple's job, education and accommodation.

These findings are in accordance with a report published by Amato (2003), suggesting that unemployment and low levels of education play important roles in divorce (Amato \& Previti, 2003). The importance of age of marriage in divorce is reported by Rotz (2016), suggesting that getting divorced is more common among women who married at younger ages (Rotz, 2016). Under age, marriage is globally recognized as a health and socially harmful issue and are investigated widely. The significant association between family size and divorce is in accordance with Amato's study (2003) who found a significant and direct association between the number of brothers and sisters and divorce of the couples (Amato \& Previti, 2003). In the present study, type of accommodation was significantly associated with 
the risk of divorce. This finding is in accordance with the results from a study published by Milosch (2014) (Milosch, 2014). The significant association between accommodation and risk of divorce is also reported by Fereidooni (2016) (Fereidouni, 2016) and Farzanegan (2016) (Farzanegan \& Gholipour, 2016) who found an opposite association between rental house and marital stability (Fereidouni, 2016). Others reported that the higher cost of accommodation seems to increase the risk of divorce (Milosch, 2014).

In line with the results of the present study, Fereidooni (2016) also reported that a wife's education is not a powerful predictor of divorce (Fereidouni, 2016). Similarly, the present study could not find any significant association between divorce history in the wife's or husband's family and the risk of their divorce. This result is not in line with Dronker's finding (2008) suggesting that women who reported the divorce of their parents were at a higher risk of divorce in their own marriages (Dronkers \& Härkönen, 2008). This is, however, worth noticing that in the present study, the reported divorce among the parents of the participating couples was infrequent making it less likely to show a statistically significant association.

The results of multivariable analysis also suggested that the age of marriage of both wife and husband made a significant contribution to the prediction of the risk of divorce. In other words, the older the couples, the higher the risk of them getting divorced. These findings are in accordance with a report published by Rotz (2016) suggesting age at marriage of couples is a strong predictor of divorce (Rotz, 2016). The association is justifiable regarding the fact that personality is less changeable as an individual gets older (Adults et al., 2018). A fixed personality, may in turn, negatively affect marriage compatibility which causes disputes between a husband and wife (Zare, Nasir, Mastor, Wan Shahrazad, \& Shahrazad, 2013).

The results of the present study also suggested that unemployment of either husband or wife is a major risk factor for divorce. The observed association between unemployment in couples and risk of divorce is in accordance with the results of a study published by Krider (2011) suggesting a strong association between couples' unemployment and the chance of divorce (Kreider \& Ellis, 2011). Unemployment limits the couples' financial ability in providing themselves with expected level of welfare which may cause disillusionment among the spouses. In this regard, an interesting finding of the present study was the positive effect of wives' employment in the prevention of divorce which seems contradictory to what is traditionally believed: wives' employment increases their financially independence of and put the marriage at higher risk (Amato \& Beattie, 2011). Indeed, the employment of wives may help in financially securing family and employed women obtain a more socialable personality and therefore become more capable of managing family disputes (Hansen, 2005).

In the present study, inverse and significant association was found between the education of husbands and the risk of divorce. Accordingly, divorce was much higher in couples with husbands who had obtained secondary education or diploma compared to those with a university degree. This finding is in accordance with the previous analogy on the importance of financial support and social skills in successful marriage (González-Val \& Marcén, 2012). Amato (2003), on the other hand, found a direct association between education and the risk of divorce (Amato \& Previti, 2003). Indeed, the authors found a higher rate of divorce among well-educated couples which was possibly due to an increase in their expectations (Amato \& Previti, 2003). One possible explanation for this discrepancy is that among marriage expectations, financial factors in Iranian couples are more important than social factors. 
The results of the current study suggested that shared accommodation is a significant predictor of divorce. Those couples with no independent accommodation experienced a higher risk of divorce. For example, couples living with their parents were at higher risk of divorce. This finding may indicate two important and yet independent issues in marriage. First, living with parents may increase the chance of family disputes and second, having independent accommodations represents better financial status of the family.

No study was found providing a divorce predicting model to be compared with.

\section{Conclusion}

This study introduced job, education, age at marriage and accommodation statuses of the couples as powerful predictors of divorce. These factors can be used to predict/prevent divorce and may help social service providers and consultants in better consulting marrying couples and help them in solving family disputes. The sensitivity and specificity of the predicting model were good enough to be discussed in more details in future works.

\section{Limitations}

Due to legal considerations, this study was able to use the information of a limited number of couples. However, the sample size was enough in studying the association of most study variables with an acceptable power. After the results of a pilot study revealed, it was decided to interview wives only as they were more cooperative. This may limit the generalizability of the results.

\section{Ethical Approval}

Ethical approval of the study was received by Yasuj University of Medical Sciences, Yasuj, Iran.

\section{Acknowledgments}

The present study is a part of research project (Divorce and its associated factors in BoyerAhmad County). 


\section{References}

Adults, O., Brown, S. L., \& Lin, I.-F. (2018). The Gray Divorce Revolution : Rising Divorce Among. The Journals of Gerontology, 67(March), 731-741. https://doi.org/10.1093/geronb/gbs089.

Amato, P. P. R., \& Beattie, B. (2011). Does the unemployment rate affect the divorce rate? An analysis of state data 1960-2005. Social Science Research, 40(3), 705-715. https://doi.org/10.1016/j.ssresearch.2010.12.012

Amato, P. P. R., \& Previti, D. (2003). People's reasons for divorcing gender, social class, the life course, and adjustment. Journal of Family Issues, 24(5), 602-626. https://doi.org/10.1177/0192513X03254507

Bernardi, F., \& Martínez-Pastor, J. I. (2011). Divorce risk factors and their variations over time in Spain. Demographic Research, 24, 771-800. https://doi.org/10.4054/DemRes.2011.24.31

Brown, S. L., \& Lin, I. F. (2012). The gray divorce revolution: Rising divorce among middleaged and older adults, 1990-2010. Journals of Gerontology - Series B Psychological Sciences and Social Sciences, 67 B(6), 731-741. https://doi.org/10.1093/geronb/gbs089

Choi, S. Y. P., \& Cheung, A. K. L. (2017). Dissimilar and Disadvantaged: Age Discrepancy, Financial Stress, and Marital Conflict in Cross-Border Marriages. Journal of Family Issues, 38(18), 2521-2544. https://doi.org/10.1177/0192513X16653436

Cooney, T. M., \& Dunne, K. (2001). Intimate relationships in later life: Current realities, future prospects. Journal of Family Issues. https://doi.org/10.1177/019251301022007003

Dronkers, J., \& Härkönen, J. (2008). The intergenerational transmission of divorce in crossnational perspective: Results from the Fertility and Family Surveys. Population Studies, 62(3), 273-288. https://doi.org/10.1080/00324720802320475

Farzanegan, M. R., \& Gholipour, H. F. (2016). Divorce and the cost of housing: evidence from Iran. Review of Economics of the Household, 14(4), 1029-1054. https://doi.org/10.1007/s11150-014-9279-0

Fereidouni, H. (2016). Housing Costs and Divorce Rate in the MENA Countries. Topics in Middle Eastern and North African Economies, 18, 0-8. Retrieved from http://ecommons.luc.edu/meea/221/

$\mathrm{Fu}, \mathrm{X}$. (2006). Impact of socioeconomic status on inter-racial mate selection and divorce. Social Science Journal, 43(2), 239-258. https://doi.org/10.1016/j.soscij.2006.02.004

Furtado, D., Marcén, M., \& Sevilla, A. (2013). Does Culture Affect Divorce? Evidence From European Immigrants in the United States. Demography, 50(3), 1013-1038. https://doi.org/10.1007/s13524-012-0180-2 
González-Val, R., \& Marcén, M. (2012). Breaks in the breaks: An analysis of divorce rates in Europe. International Review of Law and Economics, 32(2), 242-255. https://doi.org/10.1016/j.irle.2012.01.005

Gottman, J. M. (1994). What Predicts Divorce? The Relationship Between Marital Processes and Marital Outcomes. Retrieved from https://books.google.com/books?hl=en\&lr=\&id=ziABAwAAQBAJ\&oi=fnd\&pg=PP1\& $\mathrm{dq}=$ association + between + divorceed + coples + and $+\mathrm{its}+$ associated+factors $\&$ ots $=\mathrm{NW} 3 \mathrm{zx} 0$ _6Dk\&sig=Hap6Wu7t7fmIIFKmxgeUAdnZNhM

Greenwood, J., Guner, N., Santos, C., \& Kocharkov, G. (2016). Technology and the changing family: a unified model of marriage, divorce, educational attainment and marred female labor-force participation. American Economic Journal: Macroeconomics, 8(1), 1-41. https://doi.org/10.1257/mac.20130156

Hansen, H. T. (2005). Unemployment and marital dissolution: A panel data study of Norway. European Sociological Review. https://doi.org/10.1093/esr/jci009

Hochberg, A. M., \& Kressel, K. (1996). Determinants of Successful and Unsuccessful Divorce Negotiations. Journal of Divorce \& Remarriage, 25(1-2), 1-21. https://doi.org/10.1300/J087v25n01_01

Hohmann-marriott, B. B. E., \& Amato, P. (2008). Relationship quality in interethnic marriages and cohabitations. Social Forces, 87(2), 825-855. https://doi.org/10.2307/20430893

Jalovaara, M. (2003). The joint effects of marriage partners' socioeconomic positions on the risk of divorce. Demography, 40(1), 67-81. https://doi.org/10.1353/dem.2003.0004

Janmardy, M. (2011). Study of divorce in Iran provinces from 1977 to 1998 : Emphasis on the role of Iran-Iraq war. International Journal of Sociology And, 3(April), 132-138. Retrieved from http://www.academicjournals.org/journal/IJSA/articleabstract/F82635F2165

Jensen, P., \& Smith, N. (1990). Unemployment and marital dissolution. Journal of Population Economics, 3(3), 215-229. https://doi.org/10.1007/BF00163076

Karabchuk, T. (2017). Marriage and Divorce, 1994-2014. In Demography of Russia (pp. 115-153). London: Palgrave Macmillan UK. https://doi.org/10.1057/978-1-137-51850$7+4$

Kreider, R. M., \& Ellis, R. (2011). Number, Timing, and Duration of Marriages and Divorces: 2009. Current Population Reports, (May), 70-125. Retrieved from https://scholar.google.com/scholar?q=Number\%2C+timing\%2C+and+duration+of+marr iages+and+divorces \%2C+2009\&hl=en\&as_sdt=0\%2C5\&as_ylo=2010\&as_yhi=2011

Milosch, J. (2014). House Price Shocks and Individual Divorce in the United States. Retrieved from http://www.sole-jole.org/14226.pdf 
Shahraki, Sedaghat, Fararouei, and Tabeshfar

Rotz, D. (2016). Why Have Divorce Rates Fallen?: The Role of Womens Age at Marriage. Journal of Human Resources, 51(4), 961-1002. https://doi.org/10.3368/jhr.51.4.0214$6224 \mathrm{R}$

Sbarra, D. A., Hasselmo, K., \& Bourassa, K. J. (2015). Divorce and Health. Current Directions in Psychological Science, 24(2), 109-113. https://doi.org/10.1177/0963721414559125

Song, M. (2010, May). Does "race" matter? A study of "mixed race" siblings' identifications. Sociological Review. https://doi.org/10.1111/j.1467-954X.2010.01903.x

Sweeney, M. M. M. (2010). Remarriage and stepfamilies: Strategic sites for family scholarship in the 21st century. Journal of Marriage and Family, 72(3), 667-684. https://doi.org/10.1111/j.1741-3737.2010.00724.x

Walker, J. (1992). Family Transformation through Divorce and Remarriage - a Systemic Approach - Robinson,M. Journal of Family Therapy, 14(2), 207-209. Retrieved from http://books.google.com/books?hl=en\&lr=\&id=9p2KAgAAQBAJ\&oi=fnd\&pg=PP1\&d $\mathrm{q}=$ Family+Transformation+Through+Divorce+and+Remarriage:+A+Systemic + Approac h\&ots=HTbR7_6mw-\&sig=M-k55FP8_mIMOcLYokbJvVb_yrs

Wolfinger, N. H. (2011). More Evidence for Trends in the Intergenerational Transmission of Divorce: A Completed Cohort Approach Using Data From the General Social Survey. Demography, 48(2), 581-592. https://doi.org/10.1007/s13524-011-0025-4

Zare, B., Nasir, R., Mastor, K. A. K., Wan Shahrazad, W. S., \& Shahrazad, W. (2013). Personality Traits, the Risk of Divorce and Marital Satisfaction: An Intrapersonal Model. The Social Sciences, 8(5), 466-472. https://doi.org/10.3923/sscience.2013.466.472 
Shahraki, Sedaghat, Fararouei, and Tabeshfar

Table 1: Baseline Characteristics of the Participants

\begin{tabular}{|c|c|c|c|c|}
\hline Variable & & Divorced (60) & Non-divorced (64) & p-value \\
\hline Qualitative measures & & $\mathrm{N}(\%)$ & $\mathrm{N}(\%)$ & \\
\hline \multirow[t]{3}{*}{ Husband's job } & Un-employed & $15(31.25)$ & $6(9.38)$ & 0.003 \\
\hline & Employee/ Self- & $33(68.75)$ & $58(90.63)$ & \\
\hline & employed & & & \\
\hline \multirow[t]{3}{*}{ Wife's job } & homemaker & $40(78.43)$ & $34(56.67)$ & 0.01 \\
\hline & Employee/ Self- & $11(21.57)$ & $26(43.33)$ & \\
\hline & employed & & & \\
\hline \multirow[t]{2}{*}{ Accommodation statues } & Landlord & $23(45.10)$ & $42(76.36)$ & $<0.001$ \\
\hline & Tenant & $28(54.90)$ & $13(23.64)$ & \\
\hline \multirow[t]{3}{*}{ House rented } & No renting & $39(84.78)$ & $35(62.50)$ & 0.008 \\
\hline & $\leq 200$ thousands & $7(15.22)$ & $12(21.43)$ & \\
\hline & $>200$ thousands & $0(0.00)$ & $9(16.07)$ & \\
\hline \multirow[t]{3}{*}{ Bonding status } & No bonding & $37(88.10)$ & $34(61.82)$ & 0.009 \\
\hline & $\leq 4$ millions & $4(9.52)$ & $10(18.18)$ & \\
\hline & $>4$ millions & $1(2.38)$ & $11(20.00)$ & \\
\hline \multirow[t]{4}{*}{ Wife's education } & Illiterate & $6(10.17)$ & $9(14.06)$ & \\
\hline & Secondary or & $41(69.49)$ & $37(57.81)$ & 0.40 \\
\hline & diploma & & & \\
\hline & College & $12(20.34)$ & $18(28.13)$ & \\
\hline \multirow[t]{4}{*}{ Husband's education } & Illiterate & $6(10.17)$ & $11(17.19)$ & \\
\hline & Secondary or & $44(74.58)$ & $30(46.88)$ & 0.007 \\
\hline & diploma & & & \\
\hline & College & $9(15.25)$ & $23(35.94)$ & \\
\hline
\end{tabular}


Shahraki, Sedaghat, Fararouei, and Tabeshfar

Size of the husband's family $\leq 4$

$>4$

Size of the wife's family

$\leq 4$

$>4$

Divorce history in husband's No

family

Yes

No

Yes

Divorce history in spouses

family

No
Yes

$$
6(12.50)
$$

$42(87.50)$

$5(10.20)$

$44(89.80)$

46(92.00)

$4(8.00)$

$38(76.00)$

$14(22.95)$

0.16

47(77.05)

$14(23.33) \quad 0.07$

46(76.67)

48(84.21)

0.21

12(24.00)

26(54.17)

22(45.83)
10(17.54)

$9(15.79)$

47(82.46) $\quad 0.41$

49(89.09) <0.001

6(10.91) 
Shahraki, Sedaghat, Fararouei, and Tabeshfar

Table 1 Continued: Baseline Characteristics of the Participants

\begin{tabular}{|c|c|c|c|c|}
\hline \multicolumn{2}{|l|}{ Variable } & \multirow{2}{*}{$\begin{array}{l}\text { Divorced } \\
(60)\end{array}$} & \multirow{2}{*}{$\begin{array}{l}\text { Non-divorced } \\
\text { (64) }\end{array}$} & \multirow{2}{*}{$\begin{array}{l}\mathrm{p}- \\
\text { value }\end{array}$} \\
\hline & & & & \\
\hline \multirow[t]{2}{*}{ Husband's age at marriage } & $\leq 24$ years & $31(60.78)$ & $37(58.73)$ & 0.82 \\
\hline & $>24$ years & $20(39.22)$ & $26(41.27)$ & \\
\hline \multirow[t]{2}{*}{ Wife's age at marriage } & $\leq 24$ years & $42(80.77)$ & $55(87.30)$ & 0.33 \\
\hline & $>24$ years & $10(19.23)$ & $8(12.70)$ & \\
\hline \multirow[t]{4}{*}{ Type of husband's marriage } & Forced & $5(9.62)$ & $2(3.39)$ & 0.17 \\
\hline & marriage & & & \\
\hline & Consent to & $47(90.38)$ & $57(96.61)$ & \\
\hline & marriage & & & \\
\hline \multirow[t]{4}{*}{ Type of wife's marriage } & Forced & $6(11.76)$ & $6(10.00)$ & 0.76 \\
\hline & marriage & & & \\
\hline & Consent to & $45(88.24)$ & $54(90.00)$ & \\
\hline & marriage & & & \\
\hline \multirow[t]{2}{*}{ Parents' agreed sun's marriage } & Yes & $46(90.20)$ & $54(88.52)$ & 0.77 \\
\hline & No & $5(9.80)$ & $7(11.48)$ & \\
\hline \multirow{3}{*}{$\begin{array}{l}\text { Parents' agreed daughter's } \\
\text { marriage }\end{array}$} & Yes & $46(90.20)$ & $51(85.00)$ & 0.41 \\
\hline & & & & \\
\hline & No & $5(9.80)$ & $9(15.00)$ & \\
\hline \multirow[t]{2}{*}{ Consanguinity of couples } & No & $30(65.22)$ & $24(39.34)$ & 0.008 \\
\hline & Yes & $16(34.78)$ & $37(60.66)$ & \\
\hline \multirow[t]{2}{*}{ Spouses were introduced by } & Relatives & $11(37.93)$ & $23(38.33)$ & 0.97 \\
\hline & Friends & $18(62.07)$ & $37(61.67)$ & \\
\hline Husband's previous marriage & No & $43(86.00)$ & $53(94.64)$ & 0.12 \\
\hline
\end{tabular}




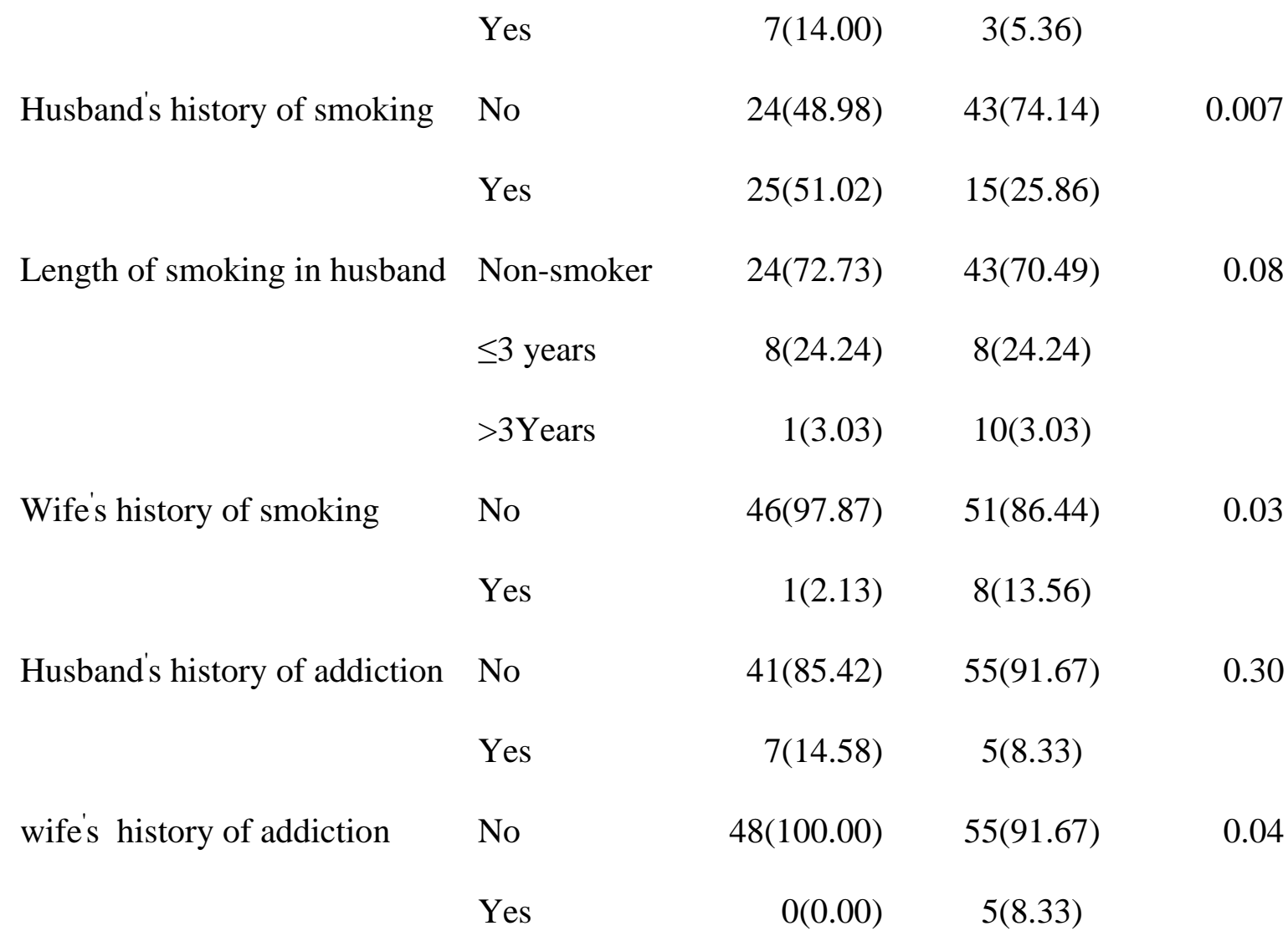


Table 2: The Adjusted Association of Study Variables and Divorce

\begin{tabular}{|c|c|c|c|c|}
\hline Variable & & OR & CI & P.value \\
\hline \multirow[t]{2}{*}{ Wife's job } & Employed & 1.00 & - & - \\
\hline & Unemployed & 4.67 & 1.38 to 21.61 & 0.019 \\
\hline \multirow[t]{2}{*}{ Husband's job } & Employed & 1.00 & - & - \\
\hline & Unemployed & 17.45 & 3.56 to 123.98 & 0.001 \\
\hline \multirow[t]{4}{*}{ Wife's education } & Secondary or & 1.00 & - & - \\
\hline & diploma & & & \\
\hline & Illiterate & 10.20 & 0.87 to 283.59 & 0.089 \\
\hline & University & 3.57 & 0.61 to 24.79 & 0.175 \\
\hline \multirow[t]{4}{*}{ Husband's education } & University & 1.00 & - & - \\
\hline & Illiterate & 0.83 & 0.015 to 22.83 & 0.91 \\
\hline & Secondary or & 23.98 & 4.04 to 237.05 & 0.001 \\
\hline & diploma & & & \\
\hline \multirow[t]{2}{*}{ Accommodation statues } & Landlord & 1.00 & - & - \\
\hline & Tanant & 5.99 & 2.54 to 17.72 & $<0.001$ \\
\hline \multirow[t]{2}{*}{ Wife's age at marriage (years) } & $\leq 24$ years & 1.00 & & \\
\hline & $>24$ years & 4.58 & 0.87 to 37.02 & 0.101 \\
\hline
\end{tabular}


Shahraki, Sedaghat, Fararouei, and Tabeshfar

Husband's age at marriage

$\leq 24$ years

1.00

(years)

$>24$ years

$2.94 \quad 0.87$ to 11.54

0.096

Figure 1: ROC Curve of the

Ability of the Logistic Model in

Predicting Divorce among

Iranians

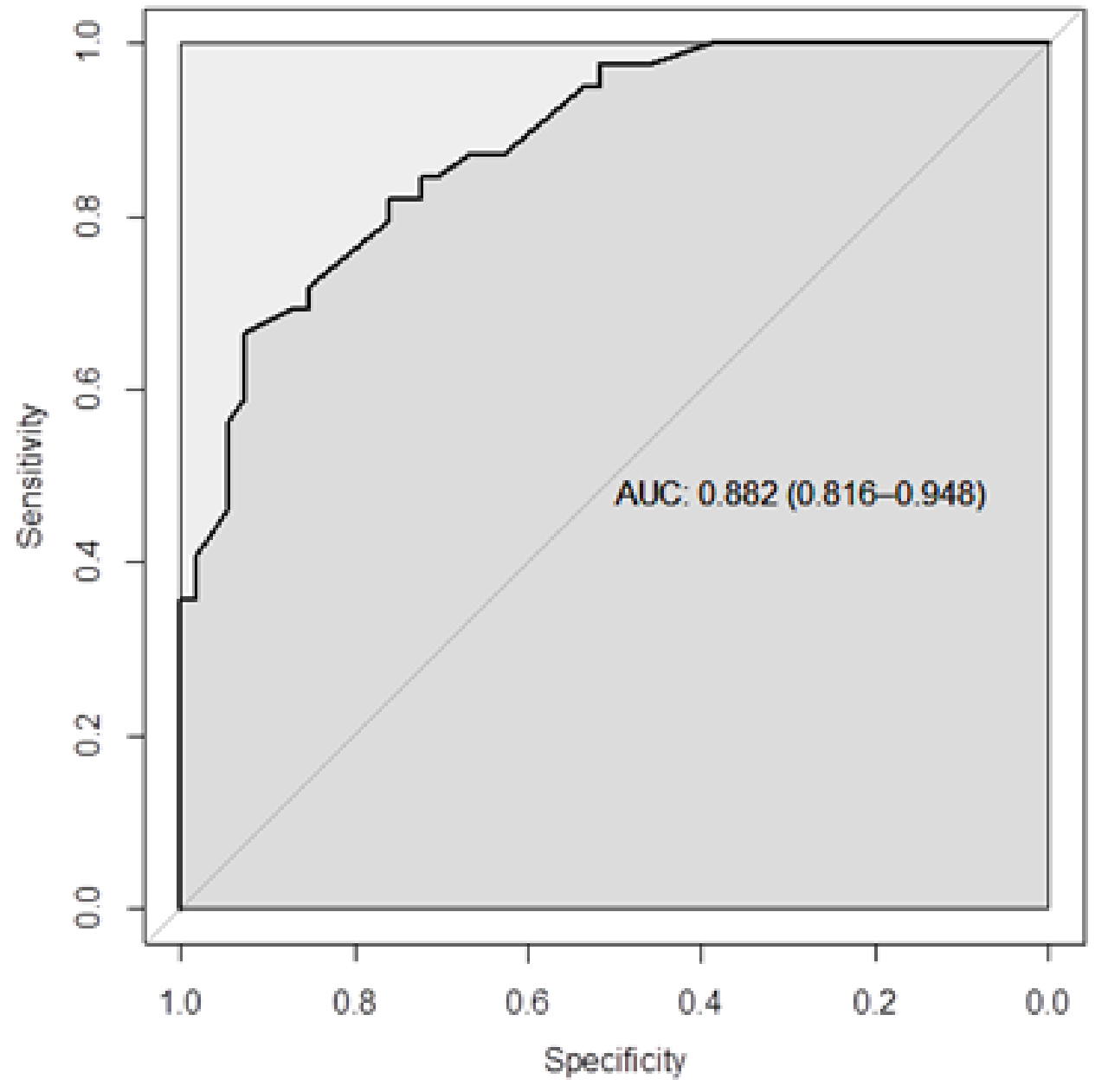

